\title{
Análise epidemiológica da prevalência da hiperidrose
}

\author{
Epidemiologic analysis of prevalence of hyperhidrosis
}

\author{
Acadêmicas: Marina Borri Wolosker, Fernanda Alvarenga Estevan \\ Orientadores: Neslon Wolosker, Pedro Puech-Leão
}

O presente estudo visa abordar de forma inédita no Brasil a prevalência das diferentes manifestações de hiperidrose (HH) em indivíduos que buscaram tratamento em ambulatório especializado em HH no estado de São Paulo. Diferentemente de trabalhos prévios, esta pesquisa estudou as diferentes combinações dos locais de sudorese, não somente se restringindo à queixa principal manifestada pelo paciente, mas levando-se em consideração as outras queixas secundárias relatadas por eles.

O trabalho foi uma abordagem retrospectiva de mais de 1200 pacientes onde foram mapeados: as combinações de locais de sudorese, a idade de aparecimento da doença, a média e espectro de idade, índice de massa corpórea e o gênero dos pacientes.

Categorizamos os pacientes em quatro grupos principais, de acordo com seu local de sudorese mais excessiva - palmar, plantar, axilar e facial.

Concluímos que a HH se manifesta mais frequentemente em mais de um local, sendo a queixa principal que mais acomete os pacientes a palmar, que aparece já na adolescência dos indivíduos. Quando há dois locais de sudorese, a combinação mais frequente é a palmo-plantar, e quando há três locais de sudorese, as combinações mais frequentes são: palmo-planto-axilar e axilo-palmo-plantar.

Palavras-chave: Hiperidrose; Epidemiologia; Sudorese; Prevalência.

The present paper aims to study the prevalence of the various manifestations of hyperhidrosis $(\mathrm{HH})$ in patients who seeked treatment in a specialized ambulatory in the state of São Paulo. Opposite to previous studies, this paper studies the different combinations of sweating sites, not being restricted to the main complaint site of the patients, but taking into consideration secondary complaints the patients may present.

This was a retrospective approach of a database that contains more than 1200 patients in which were mapped: combination of sweating sites, age of onset, age spectrum, age average, mass body index and the gender of patients.

The patients were categorized into four groups based on their main sweating site - palmar, plantar, axillary and facial.

We concluded that $\mathrm{HH}$ appears frequently in more than one site, being the main complaint that affects the most patients palmar HH, which appears early in the patients' adolescence. When there are two sites of sweating, the most frequent combination is palmar+plantar, and when there are three sites of sweating the most frequent combinations are palmar+plantar+axillary and axillary+palmar+plantar.

Keywords: Hyperhidrosis; Epidemiology; Sweating; Prevalence. 